\title{
Morro Santana e Porto Alegre: Conhecimentos Ambientais dos Alunos da Região
}

Autora: Aline Trasel Wanderlei

Orientadora: Prof ${ }^{t}$. Tais Cristine Ernst Frizzo

Resumo: O projeto de pesquisa tinha por objetivo analisar os conhecimentos dos alunos de duas diferentes instituições, do Serviço de Apoio Socioeconômico (SASE) e do Colégio de Aplicação (CAp), que estão localizadas nas proximidades do morro Santana, sobre os conhecimentos ambientais dos alunos das instituições referidas. A pesquisa foi realizada com alunos do Ensino Fundamental e foi dividida em três partes: inicialmente foi aplicado um instrumento com questões objetivas e dissertativas; a segunda parte consistia em uma palestra na qual eram abordadas informações sobre as características e a importância do morro Santana e sobre a coleta de lixo em Porto Alegre. Além disso, foram abordadas temáticas ambientais, como problemas relacionados à poluição que ocorrem no próprio município. Por último, o mesmo instrumento era reaplicado. Esse procedimento foi adotado com o objetivo de verificar se a palestra possibilitava uma melhor compreensão sobre os assuntos debatidos. Os resultados obtidos foram organizados em gráficos e comparados. Os alunos do SASE apresentaram muitas respostas equivocadas no primeiro questionário, mas se superaram quando o responderam novamente, evidenciando melhores resultados. Os alunos do CAp demonstraram, desde o preenchimento do primeiro questionário, um certo domínio do assunto, havendo ainda um aumento no número de acertos na segunda vez que responderam ao instrumento de sondagem. Os resultados mostraram que os alunos compreenderam informações importantes da palestra, podendo conhecer mais o morro Santana, local em que moram ou estudam, e pensaram sobre os impactos ambientais que temos em Porto Alegre.

Palavras-chave: Educação Ambiental; Educação Básica; Morro Santana. 